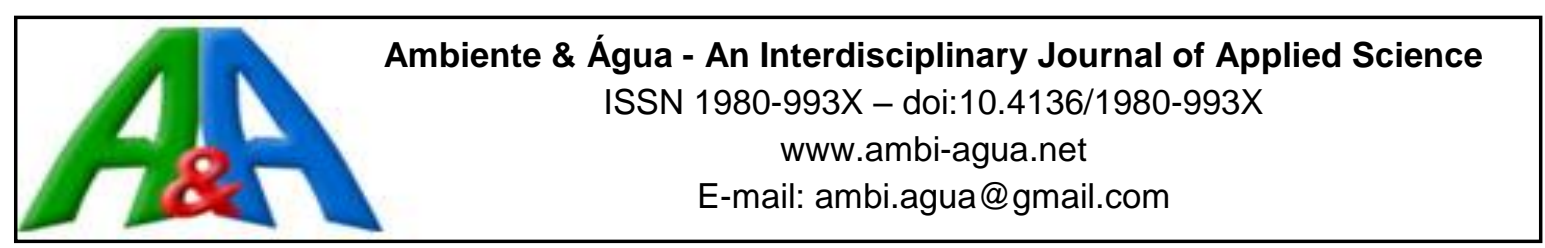

\title{
Water security in the Vale do Paraiba's basin: future scenarios
}

\author{
doi:10.4136/ambi-agua.2156
}

Received: 05 Jul. 2017; Accepted: 14 Oct. 2017

\section{Gilberto Fisch*; Thiago Adriano dos Santos; Rodrigo Cesar da Silva}

\author{
Universidade de Taubaté (UNITAU), Taubaté, SP, Brasil \\ Departamento de Ciências Agrárias. E-mail: fisch.gilberto@gmail.com, thiagoadrianodossantos@hotmail.com, \\ rodrigo.peb@gmail.com \\ *Corresponding author
}

\begin{abstract}
This paper presents general aspects of the water budget (including the latest available figures from its components), followed by some characteristics of the rainfall along the Paraiba do Sul watershed. The regional water budget theme is then discussed, taking into account the actual and future rainfall in the region. Finally, reflections and discussions regarding the water security theme (represented by the water transposition from the Paraiba do Sul watershed to the Cantareira's system) are discussed, as the latter represents the water demand of São Paulo City. The future scenarios of the water availability are estimated using a climatic simulation model.
\end{abstract}

Keywords: geoscience, water management, climatic simulations, water transposition, Cantareira system.

\section{Seguridade da água na bacia do Vale do Paraíba do Sul: cenários futuros}

\section{RESUMO}

Inicialmente, os aspectos gerais do ciclo hidrológico (incluindo os valores mais atuais de suas componentes) são apresentados, seguido de algumas características da precipitação na bacia do Rio Paraíba do Sul. Posteriormente, o balanço de água regional foi discutido levandose em conta a distribuição de chuvas do passado e do futuro da região. Finalizando, são realizadas discussões e reflexões sobre o tema de seguridade de água (representado pela transposição de água entre esta bacia hidrográfica (quantificado pelo nível de água da represa de Paraibuna) e o sistema Cantareira, que fornece água para a cidade de São Paulo. Os cenários futuros sobre a disponibilidade de água foram estimados usando simulações climáticas.

Palavras-chave: geociências, manejo de água, simulações climáticas, transposição de água, sistema Cantareira.

\section{DISCUSSION}

Climate change is one of the most remarkable and relevant threats to mankind and impacts strongly on the hydrological cycle, which affects several different activities such as industries, agriculture and lifestyle the world over. It also controls water circulation and the energy of oceans and the atmosphere, modifying weather and climate. An updated global inventory of the 
water budget is therefore necessary for climate change assessment and prediction, as well as the identification and quantification of its components and how they will change in the next decades. Figure 1 shows the latest numbers regarding the hydrological cycle performed by Rodell et al. (2015), assessing the mean annual fluxes of Earth's water cycle over continents and ocean basins. These fluxes are based on satellite and in-situ measurements integrated with results/outputs from hydrometeorological models. A careful prediction of uncertainty about these estimates is also included.

As expected, ocean evaporation (449 units) shows the highest flux and is roughly balanced by precipitation (404 units). Precipitation is low (117 units) over the continent and is not balanced by transpiration ( 71 units). This imbalance is split approximately between surface runoff (46 units) and atmospheric advection (46 units). Therefore, in general, evaporation is higher than precipitation over the ocean and the opposite (precipitation higher than evaporation) is seen inland. This surplus of water can cause some natural hazards (like flash flooding, landslides, etc).

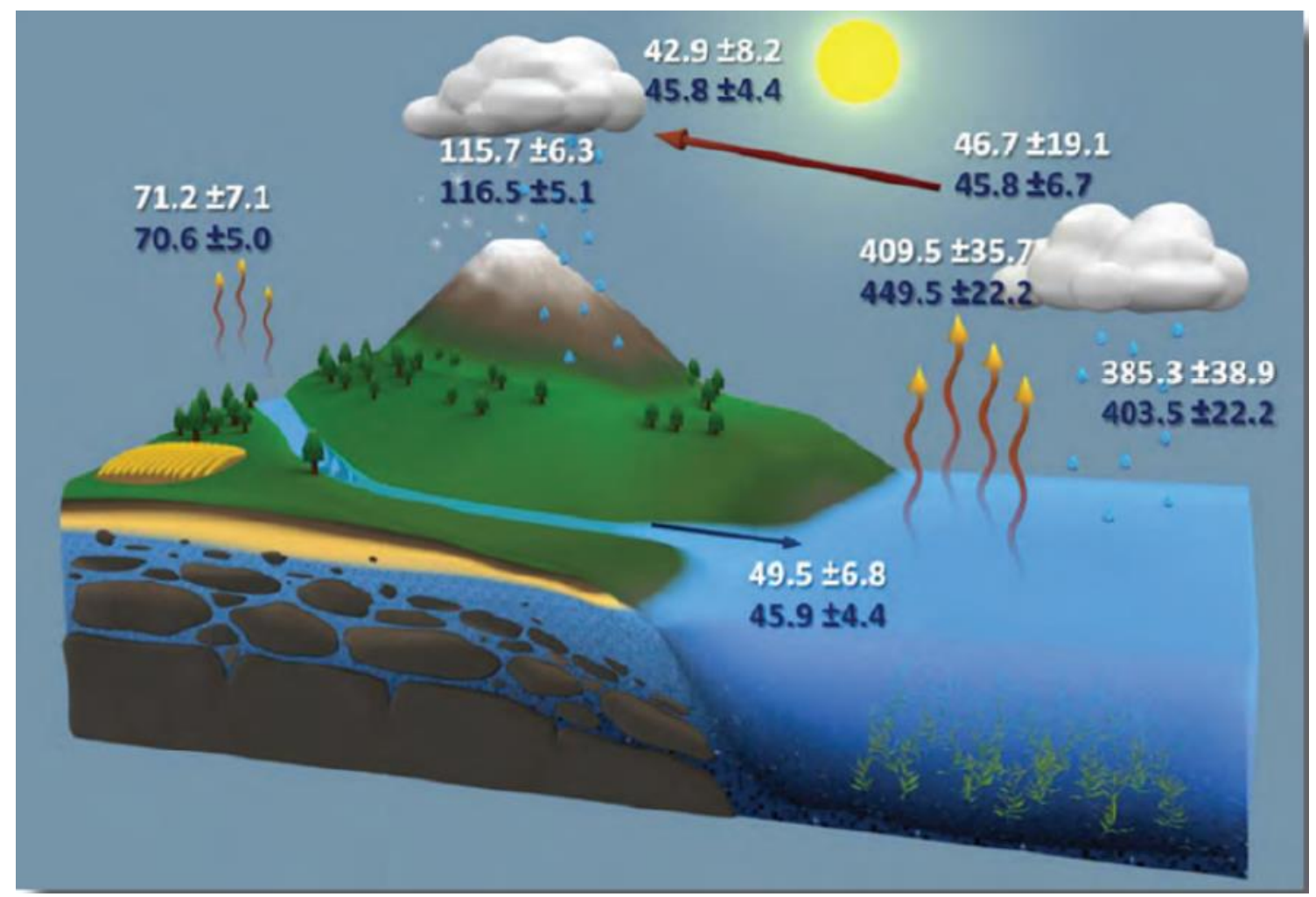

Figure 1. Global water cycle mean annual flux (units $=1000 \mathrm{~km}^{3} /$ year) and associated uncertainties.

Source: Extracted from Rodell et al. (2015).

Some countries, especially those in the wet and humid tropics, can suffer large financial and social losses due to the occurrence of natural hazards. One of these hazards is drought or dry spells. According to Bertrand and Shafer (2017), the term "drought" can be defined as a period of abnormally dry weather, sufficiently long to cause an hydrological imbalance.

Under an increasing water demand scenario caused by population increase, agricultural practices and industrialization, several criteria or tools (like instruments for planning) should be incorporated to support and quantify consequences (Mohor and Mendiondo, 2017).

The hazard mitigation polices of specific locations can guide public organizations and stakeholders so that they may take actions to reduce vulnerability of these places to extreme events that may be originated or intensified by climate change. 
According to the UN (2013), water security can be defined as the capacity of a society to safeguard sustainable water for different complex and interconnected challenges such as: a) drinking water and human well-being: b) preservation of ecosystems: c) adaptation and mitigation of hazards and climate change issues; and d) development of economic and social activities. Many factors can contribute to achieving these objectives, to include biophysical, institutional, political, social and financial factors. Moreover, in order to address this goal, transmulti-interdisciplinary collaboration among different sectors, communities and political borders is required.

A good example of the application of this theme is the Paraíba do Sul watershed, which is a region that connects 2 megacities in Brazil, São Paulo and Rio de Janeiro. Long-term assessment of water resources is highly unpredictable (Silva and Simões, 2014), and previous studies have shown a bimodal pattern of annual cycle precipitation with dry and wet seasons clearly defined. Folhes and Fisch (2006) quantified the ratio between winter and summer rainfall in relation to the annual precipitation; the values were 8 and $42 \%$, respectively, though the wet rainy period, from spring (Oct) to summer (March), can reach values close to $70 \%$. Figure 2, extracted from Silva and Simões (2014), represents the spatial distribution of the rainfall at the Paraíba do Sul watershed. The highest average precipitation is concentrated in the western part (corresponding to the Serra da Mantiqueira Ridge, with altitudes close to 2400 $\mathrm{m})$ and the northeastern portion (corresponding to the Bocaina Plateau, with altitudes of approximately $1400 \mathrm{~m}$ ). Also, the rainfall is higher in the north and lower in the south. Moreover, the spatial distribution of precipitation within the basin is directly related to the orographic role in the production and distribution of rainfall, mainly associated with the parallelism of the Serra do Mar and the Mantiqueira ridges. Moreover, the Paraitinga River and the Paraibuna Stream are located on the Serra da Bocaina plateau and form the Paraíba do Sul River, downstream the Paraibuna's Dam.

During the spring-summer period, when convective processes are more active, water vapor advection from the coast to the inland may cause intense rainfall, characterized by local showers (Vilaron and Fisch, 2014). Another important rainfall factor is the phenomenon known as the South Atlantic Convergence Zone (SACZ), which can produce high volumes of water during the spring-summer season (Silva and Simões, 2014). Recently, Coelho et al. (2017) proposed, based on statistical analysis, that the occurrence of El Nino Southern Oscillation (ENSO) events can influence the onset and the total quantity of rainfall during the wet season: the presence of a positive phase (El Nino) can advance the onset of the rainy period, producing higher overall precipitation.

In order to forecast the future climate for this important region, a Global Climate Model (UKHadCM3) model was used. Briefly, it is a numerical model of the general circulation of the planet's atmosphere and/or oceans based on mathematical equations that represent the physical processes. The model used is a fully coupled ocean-atmosphere and is widely used for projections of climate change (for instance the Assessment Report from IPCC). Obviously, all models present uncertainties about the future values computed. However, they are an important tool for planning by authorities.

For this study, the model outputs were considered (the variables were temperature and rainfall) for the period 1960-1991 (named "past") and for 2010-2040 (named "future"), with a spatial resolution of $20 \mathrm{~km}$. The model was initialized with the meteorological conditions for 1960 and was integrated until the end of the 21st century. The greenhouse effects were able to evolve with time, therefore affecting the future climate. The future scenario of growth and development of the global society was the SRES A1B, which corresponds to the actual RCP 4.5 used by the Intergovernmental Panel on Climate Change IPCC (the model and initial and boundary conditions were described in details by Santos and Fisch, 2016). 


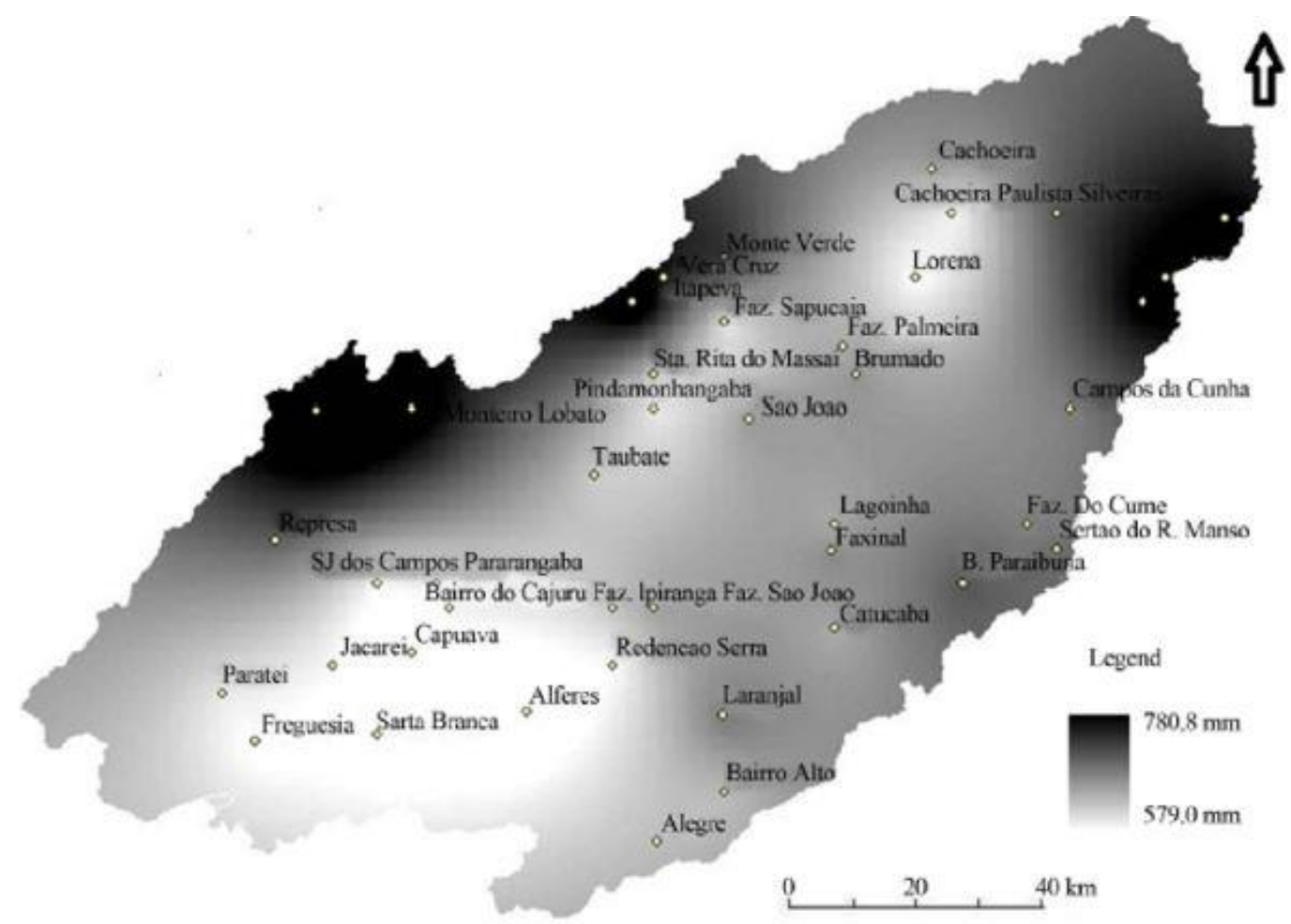

Figure 2. Spatial distribution of the rainfall at Rio Paraiba do Sul watershed.

Source: Extracted from Silva and Simões (2014).

Figure 3 shows the time series of air temperature from the wet season (October to March) for both scenarios (past and future). The increase in the temperature for both periods is very clear and unequivocal, due to an increase of greenhouse effects (Santos and Fisch, 2016). A chi squared test of the null hypothesis of the time series was applied and the differences are significant at $1 \%$.

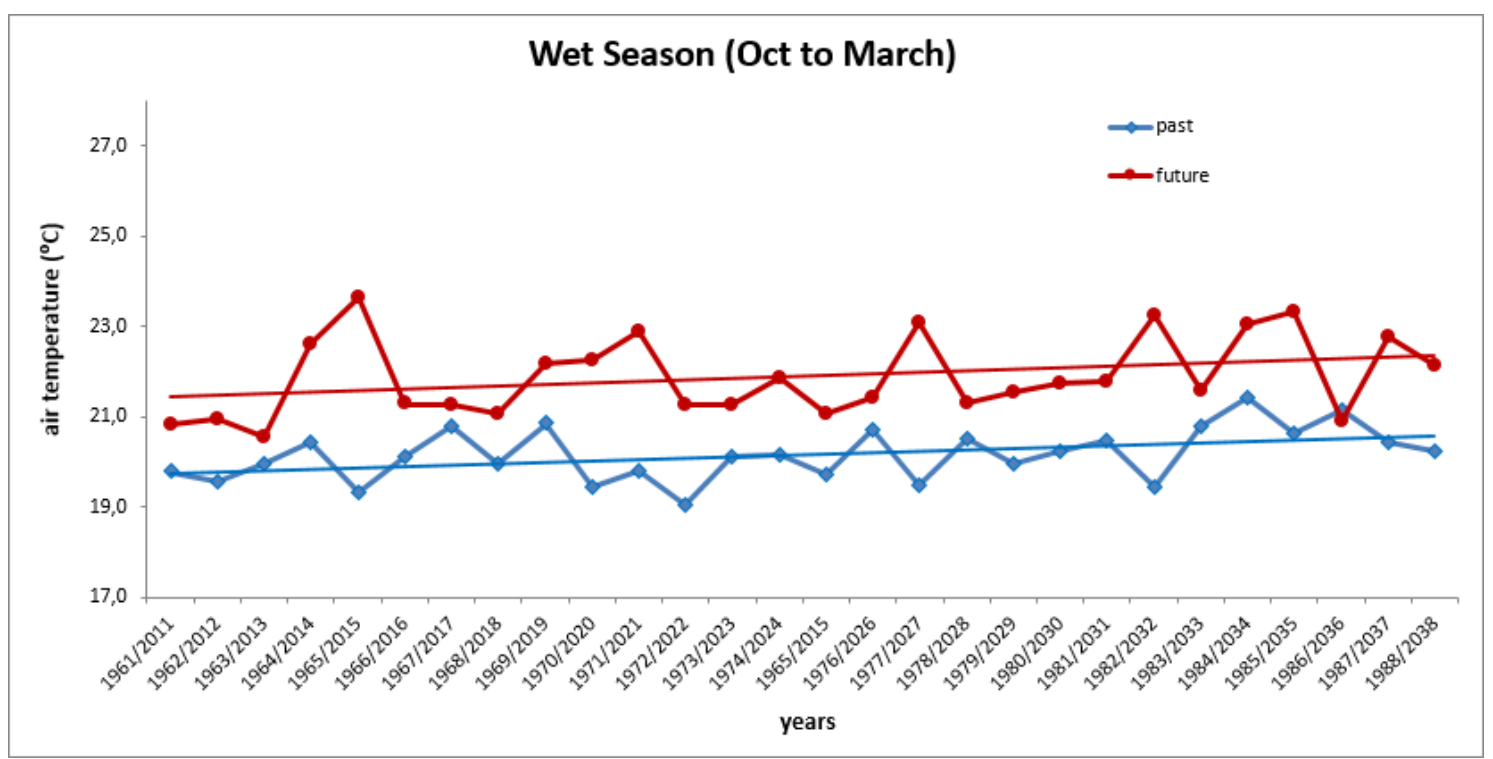

Figure 3. Time series of air temperature for past and future scenarios at Paraíba do Sul watershed.

Figure 4 shows the time series of accumulated precipitation for the wet season (October to March) for both scenarios (past and future). The values showed inter-annual variability: there are periods with higher precipitation in the future than the past and vice versa. Although the 
future scenarios predict a higher temperature for the entire planet, this is not true for precipitation, which has local and temporal variability.

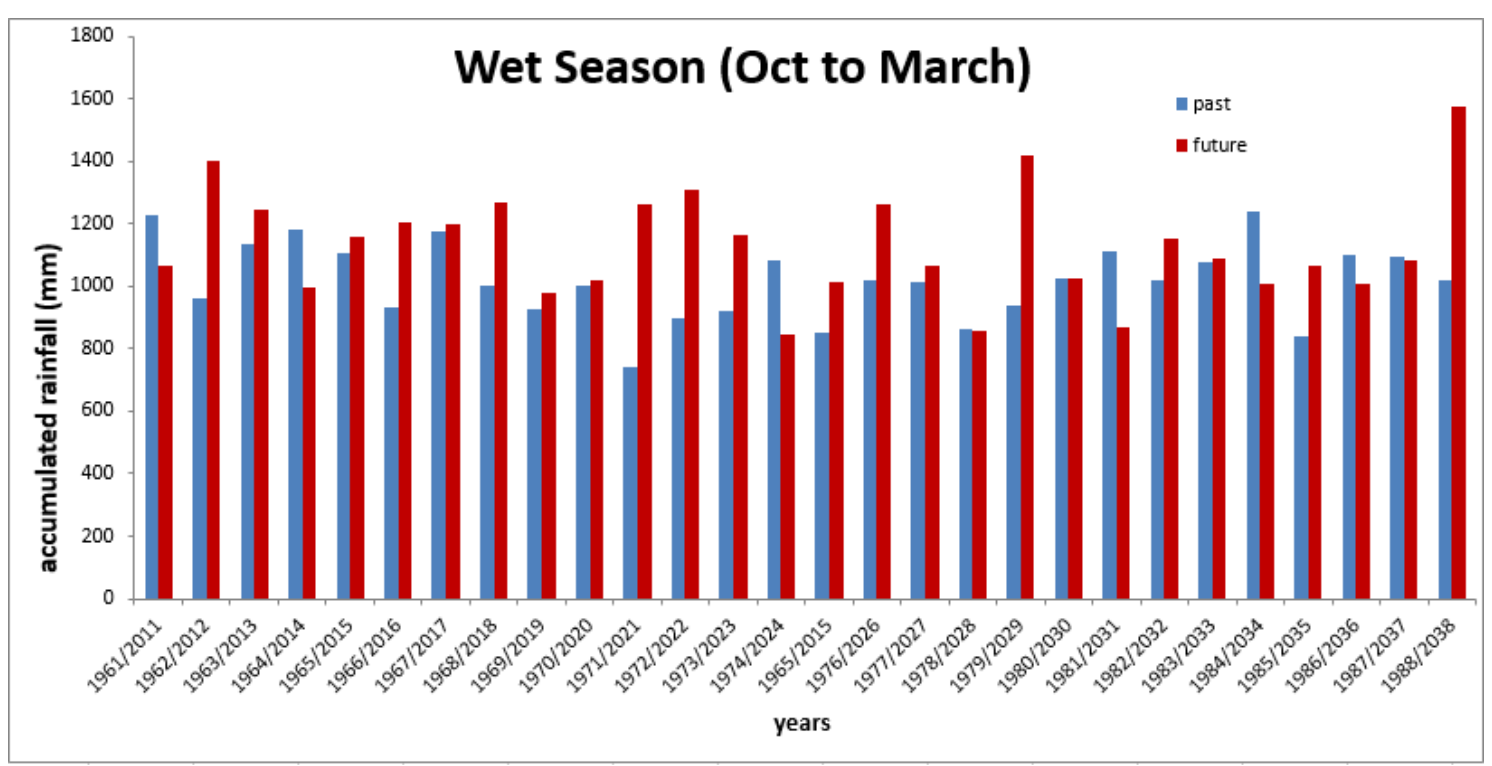

Figure 4. Time series of accumulated rainfall for past and future scenarios at Paraiba do Sul watershed.

Table 1 presents the statistics of atmospheric variables for the past (1960-1990) and future (2010-2040), generated by the model used (described at Santos and Fisch, 2016). The values presented are annual mean average, extremes (maximum and minimum) averages as well as the accumulated rainfall for annual and summer period (from October up to March). For the air temperatures, the average increase is around $1.5^{\circ} \mathrm{C}$, which allows the air to contain more moisture, as this capacity is a function of the air temperature. This is part of the reason for the increase in rainfall by $10 \%$ of the annual value, while preserving the ratio of 0.75 for the summer rainfall in relation to the annual mean value.

Table 1. The numbers in brackets are standard deviations.

\begin{tabular}{lcc}
\hline & Past (1960-1990) & Future (2010-2040) \\
\hline Air Temperature $\left({ }^{\circ} \mathbf{C}\right)$ & & \\
Mean & $20.3(0.5)$ & $21.8(0.6)$ \\
Maximum & 21.3 & 23.0 \\
Minimum & 19.2 & 20.7 \\
Rainfall (mm) & & \\
Annual & $1381(169)$ & $1514(236)$ \\
Summer & $1018(123)$ & $1129(174)$ \\
\hline
\end{tabular}

\section{FINAL REMARKS}

As pointed out by Targa and Batista (2015), the recent water deficit that occurred in São Paulo state during the years 2013-2015 strongly affected the Cantareira system (which is responsible for water supply for São Paulo City), provoked and promoted discussions and reflections about water management, including interconnected pumping between the Cantareira and Paraiba do Sul systems. However, insufficient discussions about future water availability at both basins have been conducted so far. Recently, Silva (2017) has analyzed the water availability of the Paraibuna's Dam (assuming that its volume represents the Paraiba do Sul watershed), carefully studying spatial rainfall, drainage and water storage and its possible 
transposition to the Cantareira's System. In this data processing, he included population growth and expected increase in water demand. As a result, in only $40 \%$ of the next decade will there will be enough water at Paraibuna's Dam to pump water to the Cantareira's system, without producing a deficiency in its own system. Moreover, there will be enough water for pumping just for 3 years between 2030 and 2040. Consequently, considering the future rainfall, according to the climatic model used, water transposition is not a solution.

Therefore, we conclude this editorial stating that the issue of water security is an important matter for stakeholders, society and politicians. Water security implementation should involve not only aspects of past climate conditions, but also the future climate conditions that the region may suffer in the next decades, taking into account industrialization, population growth, landuse changes, etc. Water and the environment, which is the scientific focus of this specialized journal, are strongly correlated, and knowledge must be improved using an inter-multitransdisciplinary approach.

\section{REFERENCES}

BERTRAND, D.; SHAFER, M. Defining Hazards. Bulletin of the American Meteorological Society, v. 98, n. 4, p. 659-663, 2017. http://dx.doi.org/10.1175/BAMS-D-15-00236.1

COELHO, C. A. S.; FIRPO, M. A. F.; MAIA, A. H. N.; MACLACHLAN, G. Exploring the feasibility of empirical, dynamical and combined probabilistic rainy season onset forecasts for São Paulo, Brazil. International Journal of Climatology, v. 37, p. 1-10, 2017. http://dx.doi.org/10.1002/joc.5010

FOLHES, M. T.; FISCH, G. Climate assessment and trend analysis in air temperature and precipitation time series in Taubaté (SP). Revista Ambiente \& Água, v. 1, n.1, p. 61-71, 2006. http://dx.doi.org/10.4136/ambi-agua.6

MOHOR, G. S.; MENDIONDO, E. M. Economic indicators of hydrologic drought insurance under water demand and climate change scenarios in a Brazilian context. Ecological Economics, v. 140, p. 66-78, 2017. http://dx.doi.org/10.1016/j.ecolecon.2017.04.014

RODELL, M.; BEAUDOING, H. K.; L’ECUYER, T.; OLSON, W.; FAMIGLIETTI, J. S.; HOUSER, P. R. et al. The observed state of the water cycle in the early 21 st century. $\begin{array}{lllllll}\text { Journal of } & \text { Climate, } & \text { v. 28, }\end{array}$ http://dx.doi.org/10.1175/JCLI-D-14-00555.1

SANTOS, T. A.; FISCH, G. Temperatura e precipitação: futuros cenários do município de Taubaté, SP, Brasil. Revista Ambiente \& Água, v. 11, n. 5, p. 1068-1087, 2016. http://dx.doi.org/10.4136/ambi-agua.1896

SILVA, R. D. Cenários climáticos e hidrológico futuros (2011-2040) para a represa de Paraibuna, SP, Brasil: subsídios para a transposição da água. 89 p. 2017. Dissertação (Mestrado) - Programa de Pós Graduação em Ciências Ambientais, Universidade de Taubaté, Taubaté, 2017.

SILVA, W. M.; SIMÕES, S. J. C. Spatial Intra-Annual Variability of Precipitation Based on Geostatistics. A Case Study for the Pararba Do Sul Basin, Southeastern Brazil. International Journal of Geosciences, v. 5, p. 408- 417, 2014. http://dx.doi.org/10.4236/ijg.2014.54039 
TARGA, M. S.; BATISTA, G. T. Benefits and legacy of the water crisis in Brazil. Revista Ambiente \& Água, v. 10, n.2, p. 234-239, 2015. http://dx.doi.org/10.4136/ambi-agua.1629

UNITED NATIONS - UN. Water Analytical Brief on Water Security and the Global Water Agenda. 2013. Available in: http://www.unwater.org/topics/water-security/en/. Access in: 15 maio 2017.

VILARON, M. A.; FISCH, G. Caracterização do início do período chuvoso no Vale do Paraíba $\begin{array}{lllllll}\text { paulista. Revista Ambiente \& Água, v. 8, p. 36-49, } 2014 . & \end{array}$ http://dx.doi.org/10.4136/ambi-agua. 1254 